\title{
Nitrogenase genes in non-cyanobacterial plankton: prevalence, diversity and regulation in marine waters
}

\author{
Lasse Riemann $^{1,3, *}$, Hanna Farnelid ${ }^{1}$, Grieg F. Steward ${ }^{2}$ \\ ${ }^{1}$ Department of Natural Sciences, Linnaeus University, 39182, Kalmar, Sweden \\ ${ }^{2}$ Department of Oceanography, School of Ocean \& Earth Science \& Technology, University of Hawaii, Honolulu, \\ Hawaii 96822, USA \\ ${ }^{3}$ Present address: Marine Biological Laboratory, University of Copenhagen, 3000 Helsingør, Denmark
}

\begin{abstract}
Marine waters are generally considered to be nitrogen $(\mathrm{N})$ limited and are therefore favourable environments for diazotrophs, i.e. organisms converting atmospheric $\mathrm{N}_{2}$ into ammonium or nitrogen oxides available for growth. In some regions, this import of $\mathrm{N}$ supports up to half of the primary productivity. Diazotrophic Cyanobacteria appear to be the major contributors to marine $\mathrm{N}_{2}$ fixation in surface waters, whereas the contribution of heterotrophic or chemoautotrophic diazotrophs to this process is usually regarded inconsequential. Culture-independent studies reveal that non-cyanobacterial diazotrophs are diverse, widely distributed, and actively expressing the nitrogenase gene in marine and estuarine environments. The detection of nifH genes and nifH transcripts, even in N-replete marine waters, suggests that $\mathrm{N}_{2}$ fixation is an ecologically important process throughout the oceans. Because this process is highly sensitive to and inhibited by molecular oxygen $\left(\mathrm{O}_{2}\right)$, diazotrophy requires efficient scavenging of intracellular $\mathrm{O}_{2}$ or growth in environments with low ambient $\mathrm{O}_{2}$ concentration. Particles with interior low- $\mathrm{O}_{2}$ micro-zones and oceanic oxygen minimum zones are just 2 potential habitats suitable for $\mathrm{N}_{2}$ fixation by non-cyanobacterial diazotrophs. Our ignorance about the regulation of $\mathrm{N}_{2}$ fixation by non-Cyanobacteria in their natural marine environments currently prevents an evaluation of their importance in marine $\mathrm{N}$ cycling and budgets. A review of the molecular data on distribution and expression of nifH genes in non-Cyanobacteria suggests that further study of the role of these Bacteria in N cycling at local, regional and global scales is needed.
\end{abstract}

KEY WORDS: $\mathrm{N}_{2}$ fixation $\cdot$ Nitrogen fixation $\cdot$ Non-Cyanobacteria $\cdot$ nifH $\cdot$ Nitrogenase

\section{INTRODUCTION}

Biological nitrogen $(\mathrm{N})$ fixation, the conversion of nitrogen gas $\left(\mathrm{N}_{2}\right)$ into ammonium, is widespread in the tropical and subtropical oligotrophic oceans (e.g. Capone et al. 2005), where it may fuel up to $~ 50 \%$ of new primary production (Karl et al. 1997). In contrast, this process is believed to be rather insignificant in temperate or cold pelagic oceanic regions (LaRoche \& Breitbarth 2005). Biological $\mathrm{N}_{2}$ fixation (or diazotrophy) is confined to the prokaryotic domains Bacteria and Archaea. $\mathrm{N}_{2}$-fixing Archaea appear, thus far, to be limited to the methanogens (e.g. Chien \& Zinder 1996, Mehta et al. 2005), but diazotrophy is widely distributed among diverse phenotypes and genotypes of Bacteria (Paerl \& Zehr 2000, Zehr et al. 2003b). Given the importance of $\mathrm{N}_{2}$ fixation in marine $\mathrm{N}$ cycling, identification of the organisms involved and the factors that determine their activity is essential for our understanding of ecosystem productivity and for $\mathrm{N}$ biogeochemistry (Horner-Devine \& Martiny 2008).

Cyanobacteria are the most well-studied marine diazotrophs, and filamentous forms such as the freeliving Trichodesmium spp. (Capone et al. 1997) and 
the diatom symbiont Richelia spp. (Carpenter et al. 1999) were long thought to be the only important diazotrophs in the ocean. However, molecular analyses of the nifH gene, coding for the iron (Fe) protein subunit of the nitrogenase enzyme (Zehr \& McReynolds 1989), has provided important new insights into the diversity, distribution and activity of diazotrophs. For example, Zehr et al. (2001) found evidence that $\mathrm{N}_{2}$ fixation by unicellular Cyanobacteria may equal or even exceed that of Trichodesmium in some tropical regions. The same molecular methods have also revealed putative $\mathrm{N}_{2}$-fixing non-Cyanobacteria (possessing or even expressing the nifH gene) in diverse aquatic environments (Zehr et al. 1998, Braun et al. 1999, Zani et al. 2000, Mehta et al. 2003, Steward et al. 2004b, Boström et al. 2007a) and an almost ubiquitous distribution of these diazotrophs in marine waters (Farnelid \& Riemann 2008). Still, knowledge about their importance and ecological role in the marine water column is scant, partly limited by ignorance about how $\mathrm{N}_{2}$ fixation is regulated in these organisms and where, and on what space and time scales, they are actively fixing $\mathrm{N}_{2}$.

Here we review the most recent information on the composition and distribution of non-cyanobacterial diazotrophs in marine waters. We then discuss the distribution and expression of nitrogenases in the context of environmental constraints on $\mathrm{N}_{2}$ fixation and speculate on potential loci for $\mathrm{N}_{2}$ fixation by non-Cyanobacteria in pelagic marine environments.

\section{NITROGENASE GENES FROM NON-CYANOBACTERIA ARE WIDESPREAD IN MARINE ENVIRONMENTS}

The nifH gene contains regions of sequence that are sufficiently conserved across phylogenetic groups such that they can serve as 'universal' PCR priming sites using moderately degenerate primers (Zehr \& McReynolds 1989, Kirshtein et al. 1991). Therefore, molecular studies of the diversity and composition of diazotrophic organisms have been largely based on analyses of this gene, generating one of the largest non-ribosomal gene datasets on uncultivated microorganisms (Zehr et al. 2003b). NifH genes are present in a broad spectrum of prokaryotes, and the phylogenetic relationships among these organisms based on nifH sequences are largely congruent with those determined from 16S rRNA gene sequences (Zehr et al. 2003b). This suggests that horizontal gene transfer of the nifH gene has been limited (Zehr et al. 2003b), although it has been observed for several bacterial species (Raymond et al. 2004, Kechris et al. 2006, Bolhuis et al. 2010). Consequently, nifH sequences are used to tentatively infer phylogenetic affiliations of diazotrophs in microbial communities. A single microorganism can, however, have multiple phylogenetically distinct paralogous versions of nifH (Zehr et al. 2003b). This somewhat limits the inferences that can be made about diazotroph species richness in a sample based solely on data from a clone library.

NifH gene clone libraries show that non-cyanobacterial diazotrophs are distributed throughout the 4 canonical nifH clusters (Chien \& Zinder 1996) and are widespread in lakes, estuaries and marine waters (reviewed by Zehr et al. 2003b). Proteobacterial nifH phylotypes within Cluster I (molybdenum nitrogenases from Cyanobacteria and Proteobacteria [Alpha-, Betaand Gamma- subgroups] and vanadium nitrogenases [vnfH] from Gammaproteobacteria), are particularly prevalent in marine waters (Fig. 1). For instance, similar Gammaproteobacteria have been detected in the Pacific and Atlantic Oceans, and the Arabian and South China Seas (Bird et al. 2005, Langlois et al. 2005, 2008, Church et al. 2005a, 2008, Moisander et al. 2008). Alpha- and betaproteobacterial nifH genes are also widespread and commonly detected (e.g. Zehr et al. 1998, Falcón et al. 2004, Man-Aharonovich et al. 2007, Hewson et al. 2007a, Moisander et al. 2008, Rees et al. 2009).

Few sequences within Cluster II (archaeal nitrogenases and bacterial iron nitrogenases, anfH) have been obtained from the environment (Zehr et al. 2003b), although members of both Cluster II and, more commonly, Cluster III (diverse distantly related anaerobic Bacteria such as Clostridium and sulphate reducers, Deltaproteobacteria) have been detected in coastal or estuarine waters (Affourtit et al. 2001, Jenkins et al. 2004, Steward et al. 2004a, Moisander et al. 2007, Man-Aharonovich et al. 2007, Farnelid et al. 2009), or near hydrothermal vents (Mehta et al. 2003). Cluster III phylotypes are rather uncommon in the open ocean, but do appear occasionally in clone libraries from this habitat (Langlois et al. 2005, 2008). Since the cultivated representatives within Cluster III are mostly, if not all, strict anaerobes (Zehr et al. 2003b), it has been speculated that the Cluster III phylotypes reside in anoxic microzones in the oxygenated water column, for instance on particles or in association with zooplankton (Braun et al. 1999, Church et al. 2005a, Man-Aharonovich et al. 2007). This Cluster is, however, characterised by large distances between sequences (Zehr et al. 2003b) and it may therefore be plausible, and ecologically meaningful, if many of these planktonic phylotypes in fact represent facultative anaerobic Bacteria. This possibility is supported by the fact that they are found in both the free-living and particle-attached fractions of pelagic waters (Church et al. 2005a, Farnelid et al. 2009). Finally, Cluster IV, including diver- 


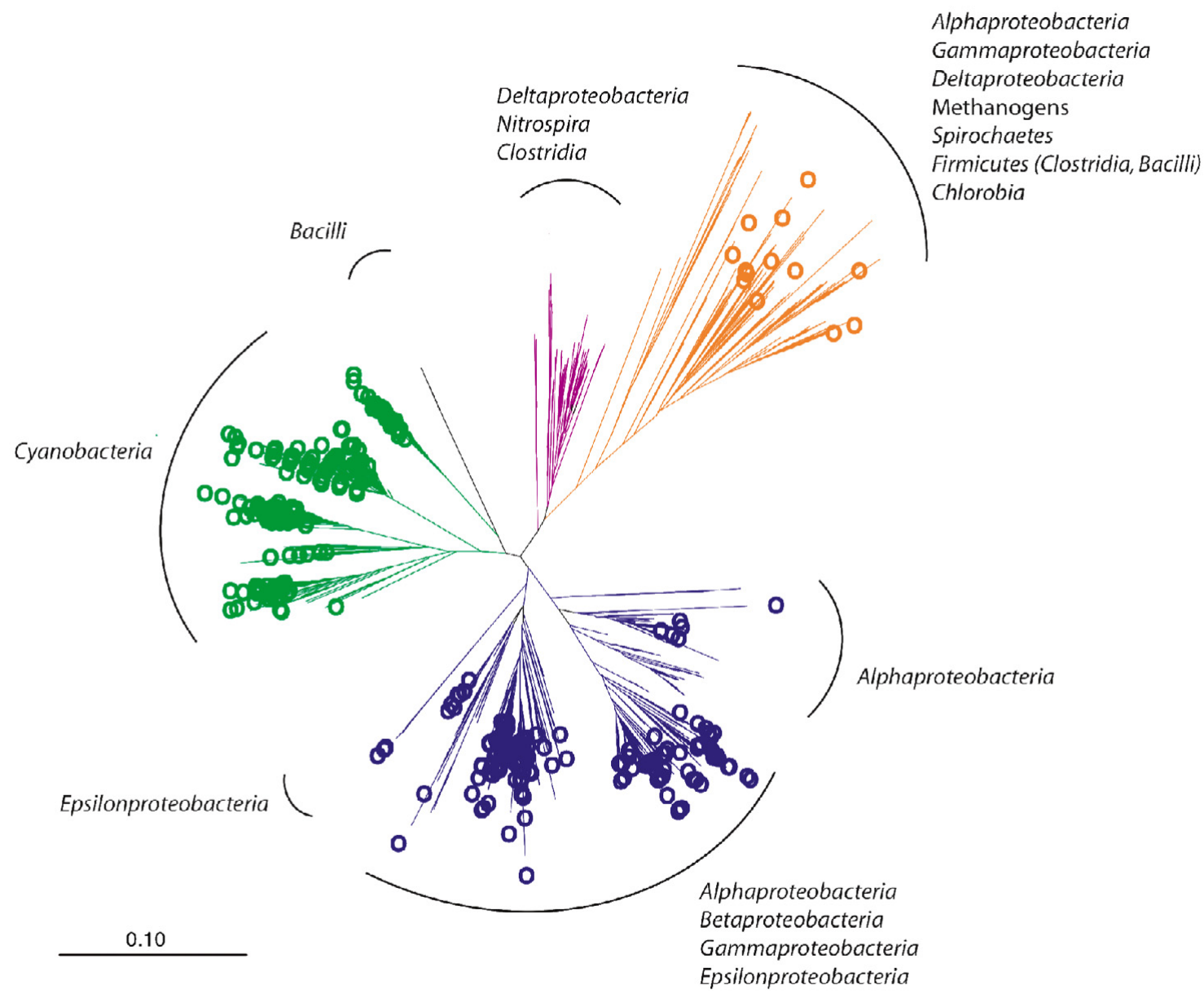

Fig. 1. Phylogenetic tree illustrating the diversity among 2570 nifH genes amplified from microorganisms in plankton samples from marine and estuarine environments. Branches derived from sequences $(n=809)$ from open ocean samples are marked with a "O". Green and blue branches belong to a loosely affiliated group of sequences designated as Cluster I (Chien \& Zinder 1996), orange branches are affiliated with Clusters II and III. Purple branches are not assigned to the traditionally defined clusters. The tree (neighbour-joining, with no distance corrections) was generated using Arb (Ludwig et al. 2004) and is based on amino acid residues 46 to 151 (Azotobacter vinelandii numbering) translated from PCR-amplified fragments of nifH genes or transcripts. Sequences were downloaded as an Arb database that was last updated on 30 March 2009 (http://pmc.ucsc.edu/ wwwzehr/ research/database/) and aligned by a hidden Markov model for nifH available at the Pfam web site (Finn et al. 2010). Sequences from marine and estuarine samples (oceans, seas, bays, gulfs, harbours, lagoons) were retrieved from the database, and those from sediments, hydrothermal vents or associated with sessile plants and animals were excluded. Open ocean samples include those from the Atlantic and Pacific Oceans and the Arabian Sea, excluding nearshore environments (gulfs, bays, harbours, fjords) and inland seas (Baltic, Mediterranean). Clusters are labelled to indicate the phylogenetic affiliations of cultivated microorganisms whose nifH sequences most closely match those from the uncultivated microorganisms shown in the tree. A total of $66 \%$ of all sequences shown are non-Cyanobacteria, and $36 \%$ of those from the open ocean are non-Cyanobacteria

gent non-functional archaeal nifH homologues, have been reported from the deep sea (Mehta et al. 2003).

Based on clone libraries, nifH sequences from nonCyanobacteria appear to be not only diverse, but also abundant relative to those of Cyanobacteria. This is particularly evident from a recent compilation of published marine nifH gene clone libraries (Farnelid \& Riemann 2008) showing that 73 to $91 \%$ (average $83 \%$ ) of the total number of nifH sequences obtained were related to nonCyanobacteria. The data compiled here (Fig. 1) similarly show that $80 \%$ of the sequences from coastal marine and estuarine plankton samples derive from nonCyanobacteria. In the open ocean the proportion is lower, with ca. $36 \%$ of the sequences deriving from nonCyanobacteria, but this likely underestimates their numerical contribution, since many oceanographic studies sample most intensively in the euphotic zone, and clone libraries from below $\sim 200 \mathrm{~m}$ consist almost exclusively of non-cyanobacterial nifH genes (e.g. Hewson et al. 2007a).

While nifH clone libraries provide convincing evidence for a near-ubiquitous distribution of non- 
cyanobacterial diazotrophs in marine waters, the information can only be considered qualitative, since endpoint PCR is not suitable for quantitative analyses (von Wintzingerode et al. 1997). In most cases, the inserts for these libraries were prepared by nested PCR amplification using degenerate primers and many cycles $(\geq 60)$, which means that the resulting clone libraries are susceptible to amplification biases (Polz \& Cavanaugh 1998). Primer bias has been observed in nifH amplifications, and the severity varies among primer sets (Demba Diallo et al. 2008). High cycle numbers, which are often required because diazotrophs typically make up a small proportion of microbial communities, also increase the chance of amplifying trace contaminants in the PCR reagents (Zehr et al. 2003a, Goto et al. 2005). It is likely that some proteobacterial nifH sequences reported to be from the environment actually originated from contaminants in PCR reagents, but this is difficult to prove conclusively. Those sequences most likely to be derived from reagent contaminants can be identified by amplification, cloning and sequencing of no-template controls and removed from sample libraries (Boström et al. 2007b).

Metagenomics is an alternative means of analysing genetic diversity that can circumvent the problems inherent in PCR. Unfortunately, this approach has not proven practical for surveys of nifH, because of the relatively low abundance of diazotrophs in assemblages of marine bacterioplankton (Johnston et al. 2005). More promising is the use of Real-Time PCR for quantification of specific nifH phylotypes. This approach circumvents some of the biases of endpoint PCR and may provide quantitative data on the spatio-temporal distribution of individual phylotypes. A significant number of recent studies have applied this approach to quantify diazotrophs in marine waters (Table 1). These data support the conclusion drawn from clone libraries that, like $\mathrm{N}_{2}$-fixing Cyanobacteria, non-cyanobacterial diazotrophs are widespread and abundant in marine waters.

In some cases Cyanobacteria are the dominant diazotrophs in marine planktonic communities (Church et al. 2005b, Zehr et al. 2007, Langlois et al. 2008, Moisander et al. 2008), but heterotrophic phylotypes are sometimes just as abundant, even in the surface ocean, as the most common cyanobacterial diazotrophs, Trichodesmium and the unicellular cyanobacterial Groups A and B (Church et al. 2005a, Fong et al. 2008). The specific diazotrophs represented in marine microbial communities vary as a function of depth. For instance, a clone library from the subtropical Atlantic Ocean suggested a shift from dominance by filamentous Cyanobacteria in the surface waters to dominance by unicellular Cyanobacteria and/or heterotrophic Bacteria in deeper waters (Langlois et al. 2005). Similarly, in the subtropical North Pacific Ocean, a Cluster III phylotype was almost as abundant as the Group A Cyanobacteria in the upper water column $\left(\sim 10^{4}\right.$ to $10^{5}$ nifH copies $\mathrm{l}^{-1}$ ), and was dominant at 100 to $200 \mathrm{~m}$ depth (Church et al. 2005a). Such observations suggest that $\mathrm{N}_{2}$ fixation may be underestimated if only illuminated surface waters are considered (Hewson et al. 2007a).

The increasing proportion of non-cyanobacterial diazotrophs with depth suggests that the distribution of these Bacteria is not constrained by light or, in contrast to oceanic Cyanobacteria (Stal 2009), by temperature. Although many of the investigations of nitrogenase gene diversity have been conducted in tropical or subtropical regions, cyanobacterial and heterotrophic diazotrophs have also been reported from temperate waters (Affourtit et al. 2001, Wasmund et al. 2001, Holl

Table 1. In situ abundance of nitrogenase (nifH) genes from non-Cyanobacteria quantified using real-time PCR

\begin{tabular}{|c|c|c|c|c|}
\hline $\begin{array}{l}\text { NifH genes } \\
\text { (copies } 1^{-1} \text { seawater) }\end{array}$ & Phylotype & Sea area & $\begin{array}{l}\text { Depth } \\
\text { (m) }\end{array}$ & Source \\
\hline 34000 & Gammaproteobacterial isolate & Baltic Sea & Surface & Boström et al. (2007a) \\
\hline $60000^{\mathrm{a}}$ & Alphaproteobacterium & South China Sea & Epipelagic & Moisander et al. (2008) \\
\hline $700^{\mathrm{a}}$ & & & Mesopelagic & \\
\hline $5000^{\mathrm{a}}$ & Gammaproteobacterium & & Mesopelagic & \\
\hline $1000-100000$ & Two phylotypes & Chesapeake Bay & $1-20$ & Short et al. (2004) \\
\hline $1000-10000$ & Gammaproteobacterium & Northern Atlantic Ocean & $5-120$ & Langlois et al. (2008) \\
\hline $16000^{\mathrm{a}}$ & Cluster III & & & \\
\hline $1000-100000^{b}$ & Cluster III & Northern Pacific Ocean & $25-200$ & Church et al. (2005a) \\
\hline $0-92000 \pm 27000$ & Gammaproteobacterium & Northern Pacific Ocean & 25 & Zehr et al. (2007) \\
\hline $10000-100000$ & Gammaproteobacterium & Northern Pacific Ocean & $0-100$ & Fong et al. (2008) \\
\hline $1-43$ & Three phylotypes & Sargasso Sea & $1000-5948$ & Hewson et al. (2007a) \\
\hline $80-700$ & Gammaproteobacterium, cDNA & Northern Pacific Ocean & $0-175$ & Church et al. (2005b) \\
\hline
\end{tabular}


et al. 2007, Man-Aharonovich et al. 2007, Needoba et al. 2007, Farnelid et al. 2009, Rees et al. 2009). For instance, in the Baltic Sea a cultivated Gammaproteobacterium was found at $3.0 \times 10^{4}$ nifH gene copies $1^{-1}$ (Boström et al. 2007a), while in Chesapeake Bay 2 proteobacterial nifH phylotypes were present at $\geq 1.4 \times$

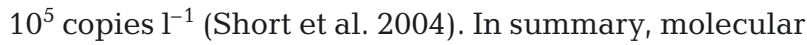
analyses of samples from pelagic marine waters strongly suggest that non-cyanobacterial diazotrophs are diverse, widely distributed, and relatively abundant, but do they actually express the nitrogenase gene? If so, which factors regulate presence and nifH expression for these phylotypes in situ?

\section{EXPRESSION OF NON-CYANOBACTERIAL nifH GENES}

Presence of non-cyanobacterial nifH genes does not necessarily imply that these microorganisms are contributing to $\mathrm{N}_{2}$ fixation. From what is known from cultivated organisms, however, the presence of nifH mRNA is a reasonable indicator of active $\mathrm{N}_{2}$ fixation (e.g. Chien \& Zinder 1996, Eady 1996, Sicking et al. 2005). For this reason, recent studies have begun to investigate the diversity among nifH transcripts in marine systems. Clone libraries based on PCR-amplified nifH cDNA from the Atlantic and Pacific Oceans as well as the Mediterranean and Arabian Seas have documented the expression of nifH by diverse noncyanobacterial (particularly proteobacterial) diazotrophs (Zehr et al. 2001, Falcón et al. 2004, Bird et al. 2005, Church et al. 2005b, Man-Aharonovich et al. 2007, Fong et al. 2008, Rees et al. 2009). For instance, non-cyanobacterial genes accounted for $88 \%$ of the 105 nifH cDNA clones sequenced from the Mediterranean Sea (Man-Aharonovich et al. 2007). In the North Pacific Subtropical Gyre, 17 \% of 135 nifH cDNA clones were related to non-Cyanobacteria (Church et al. 2005b). Only a few studies have examined the spatial distribution of these expressed phylotypes. In the North Pacific, transcript concentrations for the targeted gammaproteobacterial phylotype, on average 400 nifH cDNA copies $\mathrm{l}^{-1}$ (Church et al. 2005b), were found to be lower than those of the targeted cyanobacterial transcript concentrations in samples from $<100 \mathrm{~m}$ depth (Church et al. 2005b, Zehr et al. 2007). However, the specific expression (i.e. transcripts normalised to nifH gene concentration) for a gammaproteobacterial phylotype was comparable to or even exceeded values for targeted groups of Cyanobacteria (Zehr et al. 2007). Similarly, Real-Time PCR-derived inventories of Proteobacteria-like nifH copies in this region were as great as the inventories of the unicellular Cyanobacteria and some of the heterocystous Cyanobacteria, sug- gesting that these phylotypes account for a large fraction of the nifH containing plankton (Fong et al. 2008). Also, data from the Gulf of Aqaba in the Red Sea suggested an important role for proteobacterial diazotrophs in local $\mathrm{N}_{2}$ fixation (Foster et al. 2009). Hence, based on the relative abundance and expression of nifH genes, non-Cyanobacteria could make a significant contribution to overall $\mathrm{N}_{2}$ fixation.

A curious feature of the expression data is that only few of the phylotypes present in DNA clone libraries are present in cDNA libraries prepared from the same sample (Zani et al. 2000, Man-Aharonovich et al. 2007, Zehr \& Paerl 2008, Rees et al. 2009). Similar results have been observed in nifH-based oligonucleotide microarray studies of microbial mats and rice roots (Moisander et al. 2006, Zhang et al. 2007). These data suggest that relatively few of the diazotrophs possessing nifH in a particular environment actively transcribe the gene. The high rate of mutation in microbial populations suggests, however, that only functional genes providing a selective advantage should be fixed in a population (Berg \& Kurland 2002). Consequently, conserved genes, like nifH, should at least occasionally be expressed and encode functions of cellular importance (e.g. Tyson et al. 2004). The contrast between the DNA and cDNA data suggests that we still have much to learn about the regulation of nifH gene expression and the evolutionary pressures relevant to maintenance of this gene.

Even for those Bacteria that have been shown to transcribe the nitrogenase gene in situ, an open question is how these Bacteria cope with the conditions in the open ocean that would appear to be unfavourable for $\mathrm{N}_{2}$ fixation. For most diazotrophs, nifH expression is coordinated in response to the availability of reduced $\mathrm{N}$ and the presence of $\mathrm{O}_{2}$ (reviewed by Dixon \& Kahn 2004); however, the pelagic realm is oligotrophic, generally well oxygenated, and the bulk of the ocean's interior is replete with inorganic $\mathrm{N}$ sources. The mechanisms by which cyanobacterial diazotrophs cope with life in the open ocean has been well studied (e.g. see reviews by Bergman et al. 1997, Stal \& Zehr 2008, Stal 2009), but whether the lessons learned for cyanobacterial diazotrophs apply to non-Cyanobacteria is unknown. Below, we discuss a few selected factors that may be relevant for understanding the regulation of $\mathrm{N}_{2}$ fixation by non-Cyanobacteria.

\section{REGULATION OF NON-CYANOBACTERIAL DIAZOTROPHS IN SITU: CARBON AND NITROGEN}

Most information on the regulation of $\mathrm{N}_{2}$ fixation in heterotrophic Bacteria comes from soil studies (Gallon 
1992, Marchal \& Vanderleyden 2000, Karl et al. 2002), but some heterotrophic $\mathrm{N}_{2}$-fixing Bacteria have been isolated from seawater (Maruyama et al. 1970, Werner et al. 1974, Wynn-Williams \& Rhodes 1974, Guerinot \& Colwell 1985, Tibbles \& Rawlings 1994, Boström et al. 2007a). Transcription and translation of the nitrogenase genes, and the activity of the resulting enzyme, generally appear to be tightly regulated (Paerl \& Zehr 2000), and post-translational mechanisms regulating nitrogenase activity have also been described (e.g. Kanemoto \& Ludden 1984, Pope et al. 1985, Zehr et al. 1993). However, to what extent these findings are representative of processes occurring in the diazotrophs that inhabit marine pelagic environments is unknown.

The availability of organic carbon may limit $\mathrm{N}_{2}$ fixation in non-cyanobacterial diazotrophs due to the high energy requirements of the reaction (Zehr \& Capone 1996). Interestingly, Church et al. (2005b) observed that nifH expression by a gammaproteobacterial phylotype exhibited a slight diurnal periodicity, which may reflect a linkage to organic matter substrates provided by photoautotrophs (Zehr \& Paerl 2008). However, in clone libraries from the subtropical North Pacific, nifH transcripts clustering with Alpha- and Gammaproteobacteria were found in both day and night samples (Falcón et al. 2004). Presently, the available data from marine waters are too sparse to draw any firm conclusion about the potential carbon limitation of $\mathrm{N}_{2}$ fixation by non-Cyanobacteria.

Some marine Bacteria, in addition to growing heterotrophically, can use light-driven proton pumps to generate ATP (Béja et al. 2000). The extra energy available to photoheterotrophs growing in the light may facilitate growth in oligotrophic environments (Gómez-Consarnau et al. 2007). Some facultatively photoautotrophic Bacteria, e.g. Rhodospirillum, Rhodopseudomonas and Rhodobacter species, are able to grow diazotrophically (Meyer et al. 1978, Oelze \& Klein 1996), and nifH sequences clustering with these species have been obtained from marine waters (Zehr et al. 2003b, Moisander et al. 2008, H. Farnelid \& L. Riemann unpubl.). Moreover, photoautotrophic diazotrophs have been isolated from marine copepods (Proctor 1997). Hence, it is tempting to speculate that phototrophy helps support the high energy demands associated with $\mathrm{N}_{2}$ fixation by some non-cyanobacterial diazotrophs in the photic zone.

Unlike Cyanobacteria, putative diazotrophic nonCyanobacteria are not confined to the photic zone. Rather, their relative abundance increases with depth (e.g. Church et al. 2005a). In fact, nifH genes (e.g. Short et al. 2004, Moisander et al. 2006, Zehr et al. 2007, Hewson et al. 2007b, Langlois et al. 2008) and nifH transcripts (e.g. Bird et al. 2005, Short \& Zehr 2007, Zehr et al. 2007, Man-Aharonovich et al. 2007) from these organisms are commonly detected in environments where microbial growth would not be assumed to be limited by reduced N. For instance, nifH phylotypes were found in the vicinity of hydrothermal vents, an environment rich in reduced N (Mehta et al. 2003). Further, nifH transcripts of Gammaproteobacteria have been detected in samples from below the nutricline at nitrate/nitrite concentrations of $>5 \mu \mathrm{M}$ and in surface waters at productive coastal sites (Bird et al. 2005). For communities, noteworthy examples include measurable $\mathrm{N}_{2}$ fixation in the tropical Atlantic at nitrate concentrations of $\sim 10 \mu \mathrm{M}$ (Voss et al. 2004) and the observation that addition of ammonium and nitrate did not reduce $\mathrm{N}_{2}$ fixation in salt marsh microbial communities (Hanson 1977). Insensitivity to the presence of dissolved inorganic $\mathrm{N}$ has also been observed experimentally for some marine communities and individual isolates. For instance, Boström et al. (2007a) measured acetylene reduction by a gammaproteobacterial Baltic Sea isolate in medium amended with ammonium $(0.5 \mathrm{mM})$, and Tibbles \& Rawlings (1994) found that nitrogenase activity was only repressed by nitrate in 1 of 3 heterotrophic marine isolates. When initially grown with $\mathrm{N}_{2}$ as the sole $\mathrm{N}$ source, the nitrogenase activity of Trichodesmium was not suppressed after addition of $2 \mathrm{mM}$ nitrate or $0.02 \mathrm{mM}$ ammonium (Ohki et al. 1991), although other studies have reported inhibition of $\mathrm{N}_{2}$ fixation in Trichodesmium by nitrate (Holl \& Montoya 2005), ammonium (Capone et al. 1990) and other N sources (Mulholland \& Capone 2000). Overall, these observations contrast with the prevailing perception that $\mathrm{N}_{2}$ fixation is highly regulated by the availability of reduced inorganic N (Klugkist \& Haaker 1984 and references therein). Hence, it appears that factors other than just $\mathrm{N}$ availability influence the distribution and expression of nifH.

It has been proposed that a lack of tight ammonium regulation is a general feature of diazotrophic organisms from tropical and subtropical waters (Bird et al. 2005). Similarly, it appears that high nitrate concentrations do not select against all diazotrophs (Langlois et al. 2008). Interestingly, recent genomic data suggest that one explanation for continued $\mathrm{N}_{2}$ fixation in the presence of reduced $\mathrm{N}$ sources is that some Bacteria are simply not equipped to use other $\mathrm{N}$ sources. The genomes of 2 isolates in the marine Roseobacter clade lacked both nitrate and nitrite transporters, and experimental studies demonstrated that 1 of the strains (Silicibacter pomeroyi) could not assimilate nitrate (Moran et al. 2007). Similarly, Moore et al. (2002) found that their Prochlorococcus isolates were not able to grow with nitrate as the only $\mathrm{N}$ source, and Allen et al. (2001) observed that structural genes for nitrate assimilation (nasA) could only be amplified from certain 
marine heterotrophic Bacteria. Hence, the lack of assimilatory enzymes to utilise either nitrate or nitrite may potentially explain nitrogenase expression in $\mathrm{N}$ replete environments, as was suggested for a gammaproteobacterial diazotrophic clade found in the Arabian Sea (Bird et al. 2005). It has been suggested that organisms designed for diazotrophy have few ecological reasons to invest in a switch to nitrate uptake, since this reduction is energetically more expensive than the reduction of $\mathrm{N}_{2}$ (Karl et al. 2002). Thus, the regulation of nitrogenase expression by reduced $\mathrm{N}$ is not straightforward and most likely involves species-specific responses to specific forms of reduced inorganic $\mathrm{N}$.

\section{OXYGEN-DEPRIVED LOCI FOR $\mathrm{N}_{2}$ FIXATION BY NON-CYANOBACTERIA IN THE MARINE WATER COLUMN}

The most abundant component of our atmosphere, $\mathrm{N}_{2}$, is the substrate for the nitrogenase enzyme, while the next most abundant component, $\mathrm{O}_{2}$, not only inactivates and destroys nitrogenase, but also represses nitrogenase synthesis. Thus, protecting the nitrogenase from $\mathrm{O}_{2}$ is crucial in order for $\mathrm{N}_{2}$ fixation to occur. Using cultivation approaches based on semi-solid Ndeficient media with an $\mathrm{O}_{2}$ gradient, Guerinot \& Colwell (1985) isolated a wide variety of aerobic, facultative anaerobic and microaerophilic diazotrophs from seawater, and Boström et al. (2007a) found that heterotrophic diazotrophs from the Baltic Sea required low $\mathrm{O}_{2}$ (0 to $6 \%$ air saturation) or anaerobic conditions for $\mathrm{N}_{2}$ fixation. Similar results using other approaches have been reported (Wynn-Williams \& Rhodes 1974, Urdaci et al. 1988; see also review by Zehr et al. 2006). Hence, as has been observed for most soil Bacteria (e.g. Oelze \& Klein 1996, Marchal \& Vanderleyden 2000), marine non-cyanobacterial diazotrophs generally require anaerobic or low $\mathrm{O}_{2}$ conditions to perform $\mathrm{N}_{2}$ fixation.

Where are such conditions present in the well-oxygenated pelagic realm of the oceans? The interior of organic-rich aggregates or detritus could potentially be suitable microhabitats for $\mathrm{N}_{2}$ fixation. Particle-associated Bacteria account for $<10$ to $15 \%$ of total bacterial biomass and/or production (Turley \& Mackie 1994, Griffith et al. 1994), but during phytoplankton postbloom conditions the fraction of Bacteria attached to organic-rich aggregates can be very high (Smith et al. 1995, Riemann et al. 2000). These loci may be perceived as metabolic hot spots (Azam \& Long 2001) where extensive microbial growth (Alldredge \& Gotschalk 1990, Smith et al. 1995, Riemann et al. 2000) and thereby respiration can lead to reduced $\mathrm{O}_{2}$ concentrations in the particle interiors (Paerl \& Prufert
1987, Ploug et al. 1997). The isolation of strictly anaerobic Bacteria (Bianchi et al. 1992) together with measurements of products of anaerobic processes (Shanks \& Reeder 1993) indicate that even anoxic conditions can occur within marine aggregates, although this may be ephemeral (Ploug et al. 1997). Microbial remineralisation of freshly produced aggregates in surface waters is evident as enriched ammonia levels relative to the surrounding water (Alldredge \& Gotschalk 1990), but over time, and with depth, the microbial activity within aggregates will not only consume $\mathrm{O}_{2}$, but will also result in selective loss of $\mathrm{N}$ and phosphorus due to high rates of enzymatic hydrolysis that is uncoupled from uptake (Smith et al. 1992). Thus, the interiors of aging aggregates, with their tendency to be rich in carbon (Maruyama et al. 1970), but depleted in $\mathrm{O}_{2}$ and $\mathrm{N}$, could be suitable sites for $\mathrm{N}_{2}$ fixation.

While this idea is not new (Paerl \& Prufert 1987, Paerl 1990), experimental or field-based interrogations of this phenomenon remain scarce. However, it appears that both live and dead particulate matter could potentially serve as loci for $\mathrm{N}_{2}$-fixing non-Cyanobacteria in the marine water column (Fig. 2). In an early study, Guerinot \& Colwell (1985) found that their pure culture of a heterotrophic bacterium was only capable of $\mathrm{N}_{2}$ fixation in situ in the presence of particulate matter $>8.0 \mu \mathrm{m}$. This suggests that these Bacteria have the ability to rapidly colonise particulate matter (Kiørboe et al. 2003) and generate low- $\mathrm{O}_{2}$ conditions suitable for $\mathrm{N}_{2}$ fixation. Indeed, Paerl (1985) observed that $\mathrm{N}_{2}$ fixation by Cyanobacteria and possibly heterotrophic Bacteria paralleled the formation of low $\mathrm{O}_{2}$ microzones in aggregates. This is consistent with the more frequent detection of sequences within nifH Cluster III (related to anaerobic or facultative anaerobic Bacteria) in coastal or estuarine waters (Affourtit et al. 2001, Jenkins et al. 2004, Steward et al. 2004a, Moisander et al. 2007, Man-Aharonovich et al. 2007, Farnelid et al. 2009), which are rich in particulate matter relative to offshore environments. Non-cyanobacterial diazotrophs may also be associated with zooplankton (Proctor 1997, Braun et al. 1999) or phytoplankton. Light-driven respiration (Mehler activity) reduces $\mathrm{O}_{2}$ tension within cells and colonies of Trichodesmium, presumably allowing for $\mathrm{N}_{2}$ fixation in actively photosynthesising cells (Kana 1993). Such a mechanism may contribute to the formation of low $\mathrm{O}_{2}$ zones associated with live phytoplankton cells. We recently found diverse nifH genes from non-Cyanobacteria associated with single cells of heterotrophic dinoflagellates in the Indian Ocean (Fig. 2A-C). Light and transmission electron microscopy confirmed the presence of large heterotrophic Bacteria attached to the surfaces of the dinoflagellates (Farnelid et al. 2010). Similarly, putative diazotrophic non-Cyanobacteria have been observed on 

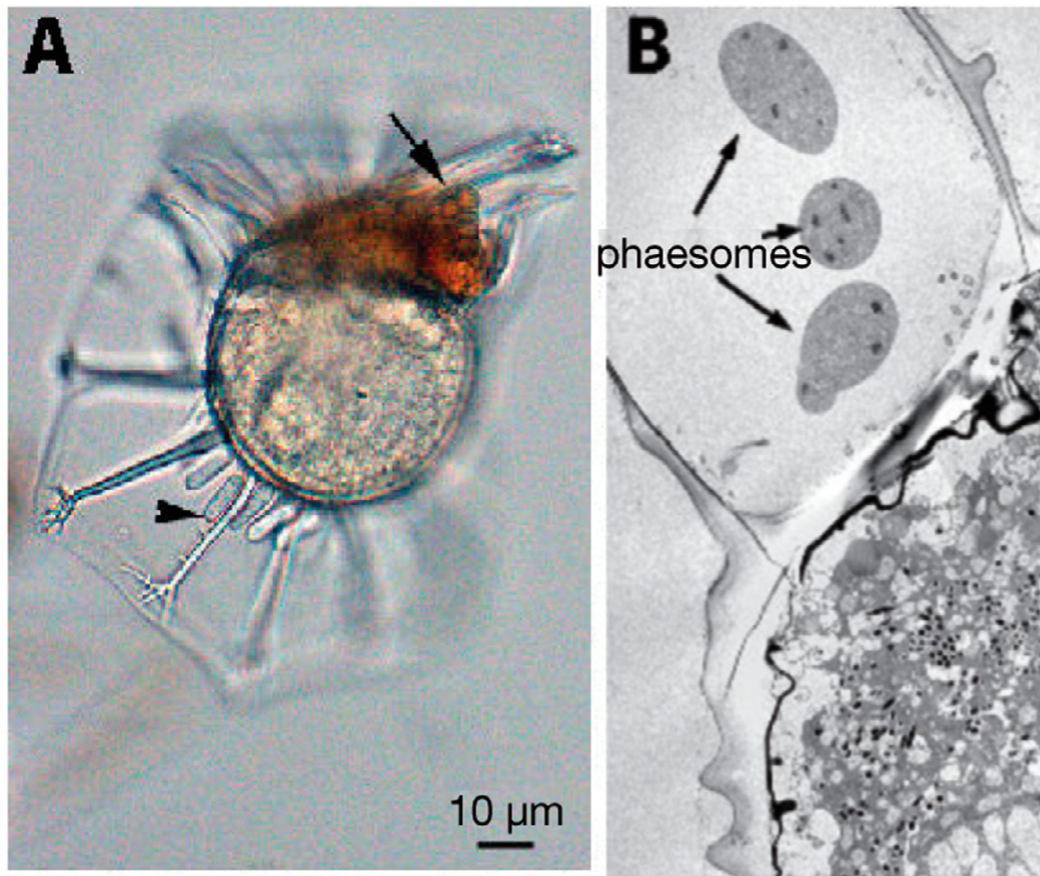

phaesomes:
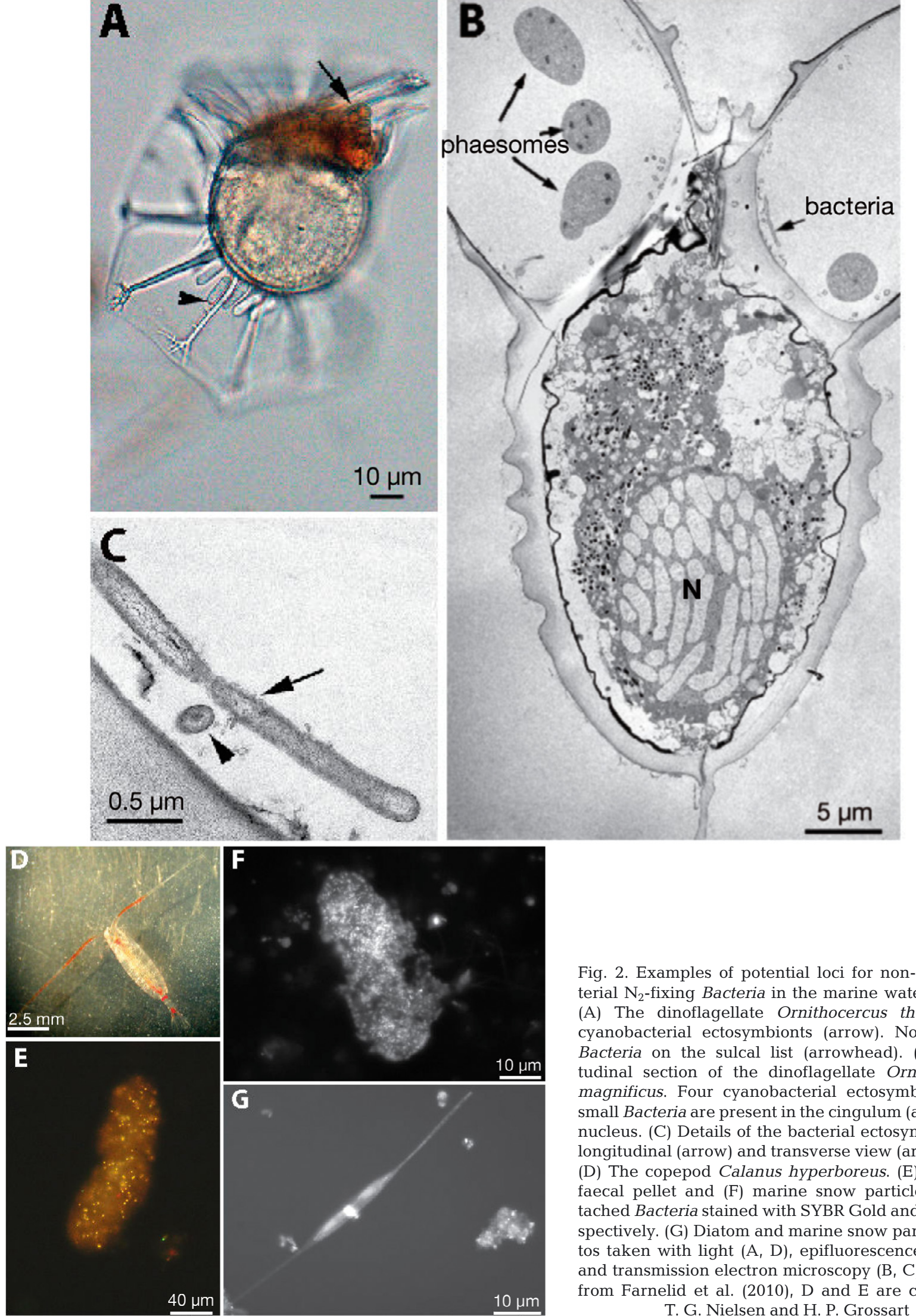

Fig. 2. Examples of potential loci for non-cyanobacterial $\mathrm{N}_{2}$-fixing Bacteria in the marine water column. (A) The dinoflagellate Ornithocercus thumii with cyanobacterial ectosymbionts (arrow). Notice large Bacteria on the sulcal list (arrowhead). (B) Longitudinal section of the dinoflagellate Ornithocercus magnificus. Four cyanobacterial ectosymbionts and small Bacteria are present in the cingulum (arrows). N: nucleus. (C) Details of the bacterial ectosymbionts, in longitudinal (arrow) and transverse view (arrowhead). (D) The copepod Calanus hyperboreus. (E) Copepod faecal pellet and $(F)$ marine snow particle with attached Bacteria stained with SYBR Gold and DAPI, respectively. (G) Diatom and marine snow particle. Photos taken with light $(A, D)$, epifluorescence $(E, F, G)$ and transmission electron microscopy $(\mathrm{B}, \mathrm{C})$. A-C are from Farnelid et al. (2010), D and E are courtesy of T. G. Nielsen and H. P. Grossart 
and within suspended $\mathrm{N}_{2}$-fixing diatom mats in the eastern Pacific (Martínez et al. 1983).

Interestingly, Dore et al. (2002) estimated higher $\mathrm{N}_{2}$ fixation rates from sedimenting particles in traps relative to rates determined from tracer incubations. The trap-derived rates agreed well with previous estimates (Deutsch et al. 2001), lending support to their accuracy. Dore et al. (2002) attributed the discrepancy to the possibility that tracer incubation underestimates true rates due to a patchy distribution of cyanobacterial diazotrophs or due to disruption of consortia (Martínez et al. 1983, Dore et al. 2002). Another source of error could be a patchy distribution of marine snow particles harbouring $\mathrm{N}_{2}$-fixing microbial assemblages. A patchy distribution of active sites of $\mathrm{N}_{2}$ fixation could help explain the discrepancy between the DNA and cDNA libraries mentioned earlier.

Considering the information summarised here, we find it conceivable that marine snow particles are ephemeral loci for $\mathrm{N}_{2}$ fixation by non-Cyanobacteria. One conceptual problem is that extensive surfaceassociated growth is required to generate low $\mathrm{O}_{2}$ microzones on marine snow particles, but mineralisation at the same time generates ammonium, which may inhibit $\mathrm{N}_{2}$ fixation. Eventually, organic $\mathrm{N}$ in a par- ticle would be exhausted, however, and $\mathrm{N}_{2}$ fixation might be possible for a short period until readily utilisable carbon is also depleted and the respiration rate is no longer sufficient to maintain low $\mathrm{O}_{2}$ conditions in the particle interior (Ploug et al. 1997). It is also possible, as noted earlier, that diazotrophs on particles are simply insensitive to the presence of fixed nitrogen.

In addition to suspended particles, interfaces between oxic and anoxic layers in the water column could be loci for $\mathrm{N}_{2}$ fixation by non-cyanobacterial diazotrophs. Anoxic basins are well known in fjords (Ramsing et al. 1996), estuaries (Hannig et al. 2006), inland seas (Lam et al. 2007) and from oceanic oxygen minimum zones (OMZs; Fig. 3), where $\mathrm{O}_{2}$ concentrations are low enough to induce anaerobic metabolism. The OMZs account for $8 \%$ of the global ocean area and play an essential role in the global N cycle (Paulmier \& RuizPino 2009), primarily due to loss of fixed $\mathrm{N}$ through denitrification (e.g. Ward et al. 2009) and anaerobic ammonia oxidation (e.g. Lam et al. 2009). In sediment studies, parallel occurrence of denitrification and $\mathrm{N}_{2}$ fixation has been shown (Fulweiler et al. 2007), yet these processes are thought to be spatially segregated in the marine water column. Recently, the co-occurrence of denitrification and $\mathrm{N}_{2}$ fixation was demonstrated in a

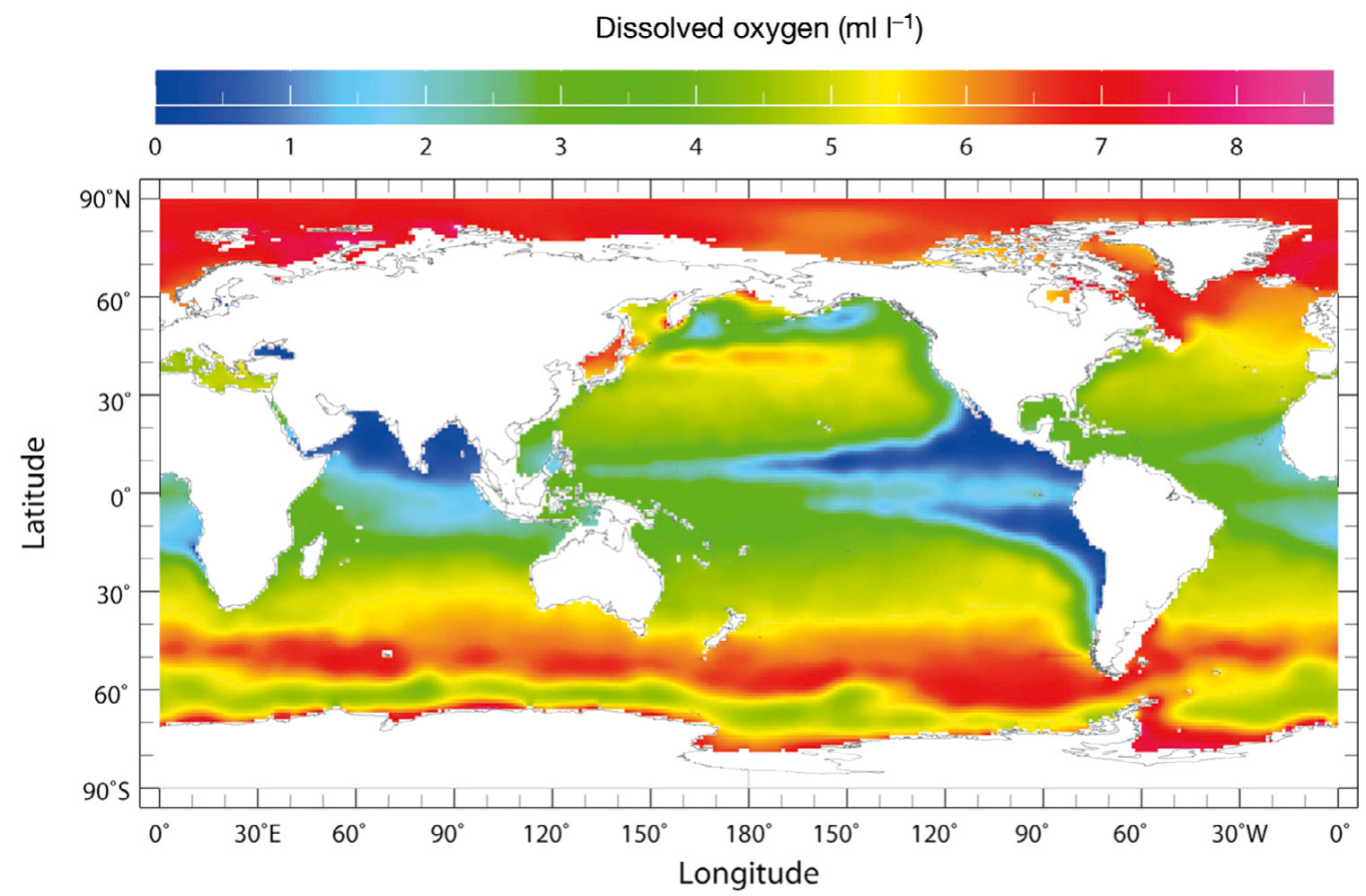

Fig. 3. Global map of major oceanic oxygen minimum zones. Annual mean dissolved oxygen levels at $200 \mathrm{~m}$ below the surface are illustrated as a colour contour plot. Areas in dark blue indicate regions with particularly pronounced subsurface oxygen minima. Data from the IRI/LDEO Climate Data Library, Columbia University (http://iridl.ldeo.columbia.edu/). Original raw data from World Ocean Atlas 2005 (Garcia et al. 2006) 
lake in association with the chemocline (Halm et al. 2009). The authors found low inorganic N concentration in the oxic zone, while in the lower anoxic zone ammonium concentrations were high. Between these zones, inorganic $\mathrm{N}$ was below detection, $\mathrm{N}_{2}$ fixation was substantial, and high levels of nifH gene expression were detected. Hence, in this system $\mathrm{N}$ loss and $\mathrm{N}$ gain occurred at the same space and time, which is very different from the conventional view of $\mathrm{N}$ cycling in the modern ocean (Halm et al. 2009).

The extent to which $\mathrm{N}_{2}$ fixation could be associated with the low $\mathrm{O}_{2}$ conditions occurring in the upper part of oceanic OMZs is currently unknown. However, the study by Halm et al. (2009) combined with the ubiquity of non-cyanobacterial diazotrophs in the ocean (Zehr et al. 2003b), even in the deep sea (Mehta et al. 2003), indicate that examination of $\mathrm{OMZ}$-associated $\mathrm{N}_{2}$ fixation could be a promising avenue.

\section{CONCLUDING REMARKS}

It is a common view that $\mathrm{N}_{2}$ fixation by non-cyanobacterial diazotrophs is not quantitatively important in the ocean. Evidence to the contrary does not yet exist, because rate measurements of $\mathrm{N}_{2}$ fixation by nonCyanobacteria, and the presumed linkage between nifH gene expression and nitrogen fixation, have not been confirmed in situ. However, an increasing number of studies reporting on the wide distribution and expression of nitrogenase genes from non-Cyanobacteria in marine pelagic waters indicates that these microorganisms are ecologically significant. Although the environmental conditions in the open ocean appear to be unfavourable for $\mathrm{N}_{2}$ fixation by non-Cyanobacteria when considered at the macroscale, the pelagic habitat is heterogeneous at small scales. $\mathrm{N}_{2}$ fixation in discrete micro-scale loci may have important consequences for carbon and nutrient cycling at local, and perhaps even global, scales.

The discovery of an unusual $\mathrm{O}_{2}$-insensitive $\mathrm{N}_{2}$ fixation pathway in a terrestrial bacterium (Ribbe et al. 1997 ) is a reminder that there may also be other pathways for $\mathrm{N}_{2}$ fixation in the ocean not captured by our current molecular tools. That observation, and the continued discovery of novel microbial ecotypes with major influences on marine biogeochemical cycling and productivity (e.g. Béja et al. 2000, Zehr et al. 2001, 2008), reflect the extraordinary metabolic innovation that characterises the prokaryotic world. Consequently, it is reasonable to expect that strategies to circumvent the presumed chemical and physical constraints on $\mathrm{N}_{2}$ fixation in the oligotrophic open oceans have evolved among some non-Cyanobacteria. We anticipate that the future of this field will soon be one in which we are no longer asking whether nonCyanobacteria fix $\mathrm{N}_{2}$ in the open ocean, but are determining how they do so and at what magnitude.

Acknowledgements. This work was supported by the Swedish Research Council FORMAS (217-2006-342 to L.R.). Contributions by G.F.S. were supported by the US National Science Foundation (NSF), the Center for Microbial Oceanography - Research and Education, and the Agouron Institute. We thank J.P. Zehr for providing public access to the aligned nifH sequence database.

\section{LITERATURE CITED}

Affourtit J, Zehr J, Paerl H (2001) Distribution of nitrogen-fixing microorganisms along the Neuse River Estuary, North Carolina. Microb Ecol 41:114-123

Alldredge AL, Gotschalk C (1990) The relative contribution of marine snow of different origins to biological processes in coastal waters. Cont Shelf Res 10:41-58

Allen AE, Booth MG, Frischer ME, Verity P, Zehr JP, Zani S (2001) Diversity and detection of nitrate assimilation genes in marine bacteria. Appl Environ Microbiol 67:5343-5348

Azam F, Long RA (2001) Sea snow microcosms. Nature 414: 495-498

Béja O, Aravind L, Koonin EV, Suzuki MT and others (2000) Bacterial rhodopsin: evidence for a new type of phototrophy in the sea. Science 289:1902-1906

> Berg OG, Kurland CG (2002) Evolution of microbial genomes: sequence acquisition and loss. Mol Biol Evol 19: 2265-2276

Bergman B, Gallon JR, Rai AN, Stal L (1997) N $\mathrm{N}_{2}$ Fixation by non-heterocystous cyanobacteria. FEMS Microbiol Rev 19:139-185

> Bianchi M, Marty D, Teyssié JL, Fowler SW (1992) Strictly aerobic and anaerobic Bacteria associated with sinking particulate matter and zooplankton fecal pellets. Mar Ecol Prog Ser 88:55-60

Bird C, Martinez M, O'Donnell AG, Wyman M (2005) Spatial distribution and transcriptional activity of an uncultured clade of planktonic diazotrophic $\gamma$-Proteobacteria in the Arabian Sea. Appl Environ Microbiol 71:2079-2085

Bolhuis H, Severin I, Confurius-Guns V, Wollenzien UIA, Stal LJ (2010) Horizontal transfer of the nitrogen fixation gene cluster in the cyanobacterium Microcoleus chthonoplastes. ISME J 4:121-130

Boström KH, Riemann L, Kühl M, Hagström Å (2007a) Isolation and gene quantification of heterotrophic $\mathrm{N}_{2}$-fixing bacterioplankton in the Baltic Sea. Environ Microbiol 9:152-164

Boström KH, Riemann L, Zweifel UL, Hagström A (2007b) Nodularia sp. nifH gene transcripts in the Baltic Sea proper. J Plankton Res 29:391-399

> Braun ST, Proctor LM, Zani S, Mellon MT, Zehr JP (1999) Molecular evidence for zooplankton-associated nitrogenfixing anaerobes based on amplification of the nifH gene. FEMS Microbiol Ecol 28:273-279

> Capone DG, O'Neil JM, Zehr J, Carpenter EJ (1990) Basis for diel variation in nitrogenase activity in the marine planktonic cyanobacterium Trichodesmium thiebautii. Appl Environ Microbiol 56:3532-3536

Capone DG, Zehr JP, Paerl HW, Bergman B, Carpenter EJ (1997) Trichodesmium, a globally significant marine cyanobacterium. Science 276:1221-1229 
Capone DG, Burns JA, Montoya JP, Subramaniam A and others (2005) Nitrogen fixation by Trichodesmium spp.: an important source of new nitrogen to the tropical and subtropical North Atlantic Ocean. Global Biogeochem Cycles 19:GB2024 doi:10.1029/2004GB002331

> Carpenter EJ, Montoya JP, Burns JA, Mulholland MR, Subramaniam A, Capone DG (1999) Extensive bloom of $\mathrm{N}_{2}$-fixing diatom/cyanobacterial association in the tropical Atlantic Ocean. Mar Ecol Prog Ser 185:273-283

> Chien YT, Zinder SH (1996) Cloning, functional organization, transcript studies, and phylogenetic analysis of the complete nitrogenase stuctural genes (nifHDK2) and associated genes in the Archaeon Methanosarcina barkeri 227. J Bacteriol 178:143-148

> Church MJ, Jenkins BD, Karl DM, Zehr JP (2005a) Vertical distributions of nitrogen-fixing phylotypes at Stn ALOHA in the oligotrophic North Pacific Ocean. Aquat Microb Ecol 38:3-14

> Church MJ, Short CM, Jenkins BD, Karl DM, Zehr JP (2005b) Temporal patterns of nitrogenase gene (nifH) expression in the oligotrophic North Pacific Ocean. Appl Environ Microbiol 71:5362-5370

Church MJ, Björkman KM, Karl DM, Saito MA, Zehr JP (2008) Regional distributions of nitrogen-fixing Bacteria in the Pacific Ocean. Limnol Oceanogr 53:63-77

> Demba Diallo M, Rheinhold-Hurek B, Hurek T (2008) Evaluation of PCR primers for universal nifH gene targeting and for assessment of transcribed nifH pools in roots of Oryza longistaminata with and without low nitrogen input. FEMS Microbiol Ecol 65:220-228

> Deutsch C, Gruber N, Key RM, Sarmiento JL (2001) Denitrification and $\mathrm{N}_{2}$ fixation in the Pacific Ocean. Global Biogeochem Cycles 15:483-506 doi:10.1029/2000GB 001291

Dixon R, Kahn D (2004) Genetic regulation of biological nitrogen fixation. Nat Rev Microbiol 2:621-631

Dore JE, Brum JR, Tupas LM, Karl DM (2002) Seasonal and interannual variability in sources of nitrogen supporting export in the oligotrophic suptropical North Pacific Ocean. Limnol Oceanogr 47:1595-1607

Eady RR (1996) Structure-function relationships of alternative nitrogenases. Chem Rev 96:3013-3030

Falcón LI, Carpenter EJ, Cipriano F, Bergman B, Capone DG (2004) $\mathrm{N}_{2}$ fixation by unicellular bacterioplankton from the Atlantic and Pacific Oceans: phylogeny and in situ rates. Appl Environ Microbiol 70:765-770

Farnelid H, Riemann L (2008) Heterotrophic $\mathrm{N}_{2}$-fixing bacteria: overlooked in the marine nitrogen cycle? In: Couto GN (ed) Nitrogen fixation research progress. Nova Science Publishers, New York, NY, p 409-423

Farnelid H, Öberg T, Riemann L (2009) Identity and dynamics of putative $\mathrm{N}_{2}$-fixing picoplankton in the Baltic Sea proper suggest complex patterns of regulation. Environ Microbiol Rep 1:145-154

Farnelid H, Tarangkoon W, Hansen G, Hansen PJ, Riemann L (2010) Putative $\mathrm{N}_{2}$-fixing heterotrophic bacteria associated with dinoflagellate-Cyanobacteria consortia in the lownitrogen Indian Ocean. Aquat Microb Ecol 61:105-117

Finn RD, Mistry J, Tate J, Coggill P and others (2010) The Pfam protein families database. Nucleic Acids Res 38: D211-D222

Fong AA, Karl DM, Lukas R, Letelier RM, Zehr JP, Church MJ (2008) Nitrogen fixation in an anticyclonic eddy in the oligotrophic North Pacific Ocean. ISME J 2:663-676

Foster RA, Paytan A, Zehr JP (2009) Seasonality of $\mathrm{N}_{2}$ fixation and NifH gene diversity in the Gulf of Aqaba (Red Sea). Limnol Oceanogr 54:219-233
Fulweiler RW, Nixon SW, Buckley BA, Granger SL (2007) Reversal of the net dinitrogen gas flux in coastal marine sediments. Nature 448:180-182

Gallon JR (1992) Reconciling the incompatible: $\mathrm{N}_{2}$ fixation and $\mathrm{O}_{2}$. New Phytol 122:571-609

Garcia HE, Locarnini RA, Boyer TP, Antonov JI (2006) World Ocean Atlas 2005, Vol 3: dissolved oxygen, apparent oxygen utilization, and oxygen saturation. Levitus $\mathrm{S}$ (ed) NOAA Atlas NESDIS 63, US Government Printing Office, Washington, DC

Gómez-Consarnau L, Gonzalez JM, Coll-Llado M, Gourdon P, Pascher T, Neutze R, Pedrós-Alió C, Pinhassi J (2007) Light stimulates growth of proteorhodopsin-containing marine Flavobacteria. Nature 445:210-213

Goto M, Ando S, Hachisuka Y, Yoneyama T (2005) Contamination of diverse nifH and nifH-like DNA into commercial PCR primers. FEMS Microbiol Lett 246:33-38

Griffith P, Shiah FK, Gloersen K, Ducklow HW, Fletcher M (1994) Activity and distribution of attached Bacteria in Chesapeake Bay. Mar Ecol Prog Ser 108:1-10

Guerinot ML, Colwell RR (1985) Enumeration, isolation, and characterization of $\mathrm{N}_{2}$-fixing Bacteria from seawater. Appl Environ Microbiol 50:350-355

Halm H, Musat N, Lam P, Langlois RJ and others (2009) Cooccurrence of denitrification and nitrogen fixation in a meromictic lake, Lake Cadagno (Switzerland). Environ Microbiol 11:1945-1958

Hannig M, Braker G, Dippner J, Jürgens K (2006) Linking denitrifier community structure and prevalent biogeochemical parameters in the pelagial of the central Baltic Proper (Baltic Sea). FEMS Microbiol Ecol 57:260-271

> Hanson RB (1977) Nitrogen fixation (acetylene reduction) in a salt marsh amended with sewage sludge and organic carbon and nitrogen compounds. Appl Environ Microbiol 33: 846-852

> Hewson I, Moisander PH, Achilles KM, Carlson CA, Jenkins BD, Mondragon EA, Morrison AE, Zehr JP (2007a) Characteristics of diazotrophs in surface to abyssopelagic waters of the Sargasso Sea. Aquat Microb Ecol 46:15-30

Hewson I, Moisander PH, Morrison AE, Zehr JP (2007b) Diazotrophic bacterioplankton in a coral reef lagoon: phylogeny, diel nitrogenase expression and response to phosphate enrichment. ISME J 1:78-91

Holl CM, Montoya JP (2005) Interactions between nitrate uptake and nitrogen fixation in continuous cultures of the marine diazotroph Trichodesmium (cyanobacteria). J Phycol 41:1178-1183

> Holl CM, Waite AM, Pesant S, Thompson PA, Montoya JP (2007) Unicellular diazotrophy as a source of nitrogen to Leeuwin Current coastal eddies. Deep-Sea Res II 54: 1045-1054

Horner-Devine MC, Martiny AC (2008) News about nitrogen. Science 320:757-758

Jenkins BD, Steward GF, Short SM, Ward BB, Zehr JP (2004) Fingerprinting diazotroph communities in the Chesapeake Bay by using a DNA macroarray. Appl Environ Microbiol 70:1767-1776

Johnston AWB, Li Y, Ogilvie L (2005) Metagenomic marine nitrogen fixation - feast or famine? Trends Microbiol 13: 416-420

Kana TM (1993) Rapid oxygen cycling in Trichodesmium thiebautii. Limnol Oceanogr 38:18-24

> Kanemoto RH, Ludden PW (1984) Effect of ammonia, darkness, and phenazine methosulfate on whole-cell nitrogenase activity and Fe protein modification in Rhodospirillum rubrum. J Bacteriol 158:713-720

Karl D, Letelier R, Tupas L, Dore J, Christian J, Hebel D (1997) The role of nitrogen fixation in biogeochemical cycling in the subtropical North Pacific Ocean. Nature 388:533-538 
Karl DM, Michaels AF, Bergman B, Capone DG and others (2002) Dinitrogen fixation in the world's oceans. Biogeochemistry 57-58:47-98

Kechris KJ, Lin JC, Bickel PJ, Glazer AN (2006) Quantitative exploration of the occurrence of lateral gene transfer by using nitrogen fixation genes as a case study. Proc Natl Acad Sci USA 103:9584-9589

Kiørboe T, Tang K, Grossart HP, Ploug H (2003) Dynamics of microbial communities on marine snow aggregates: colonization, growth, detachment, and grazing mortality of attached bacteria. Appl Environ Microbiol 69:3036-3047

Kirshtein JD, Paerl HW, Zehr JP (1991) Amplification, cloning, and sequencing of a nifH segment from aquatic microorganisms and natural communities. Appl Environ Microbiol 57:2645-2650

> Klugkist J, Haaker H (1984) Inhibition of nitrogenase activity by ammonium chloride in Azotobacter vinelandii. J Bacteriol 157:148-151

Lam P, Jensen MM, Lavik G, McGinnis DF and others (2007) Linking crenarchaeal and bacterial nitrification to anammox in the Black Sea. Proc Natl Acad Sci USA 104: 7104-7109

Lam P, Lavik G, Jensen MM, van de Vossenberg J and others (2009) Revising the nitrogen cycle in the Peruvian oxygen minimum zone. Proc Natl Acad Sci USA 106:4752-4757

> Langlois RJ, LaRoche J, Raab PA (2005) Diazotrophic diversity and distribution in the tropical and subtropical Atlantic Ocean. Appl Environ Microbiol 71:7910-7919

> Langlois RJ, Hummer D, LaRoche J (2008) Abundances and distributions of the dominant nifH phylotypes in the Northern Atlantic Ocean. Appl Environ Microbiol 74: 1922-1931

> LaRoche J, Breitbarth E (2005) Importance of the diazotrophs as a source of new nitrogen in the ocean. J Sea Res 53: $67-91$

Ludwig W, Strunk O, Westram R, Richter L and others (2004) ARB: a software environment for sequence data. Nucl Acids Res 32:1363-1371

Man-Aharonovich D, Kress N, Zeev EB, Berman-Frank I, Beja O (2007) Molecular ecology of nifH genes and transcripts in the eastern Mediterranean Sea. Environ Microbiol 9: $2354-2363$

Marchal K, Vanderleyden J (2000) The "oxygen paradox" of dinitrogen-fixing bacteria. Biol Fertil Soils 30:363-373

Martínez L, Silver MW, King JM, Alldredge AL (1983) Nitrogen fixation by floating diatom mats: a source of new nitrogen to oligotrophic ocean waters. Science 221: $152-154$

> Maruyama Y, Taga N, Matsuda O (1970) Distribution of nitrogen-fixing Bacteria in the Central Pacific Ocean. J Oceanogr Soc Jpn 26:360-366

Mehta MP, Butterfield DA, Baross JA (2003) Phylogenetic diversity of nitrogenase (nifH) genes in deep-sea and hydrothermal vent environments of the Juan de Fuca Ridge. Appl Environ Microbiol 69:960-970

> Mehta MP, Huber JA, Baross JA (2005) Incidence of novel and potentially archaeal nitrogenase genes in the deep Northeast Pacific Ocean. Environ Microbiol 7:1525-1534

Meyer J, Kelley BC, Vignais PM (1978) Effect of light on nitrogenase function and synthesis in Rhodopseudomonas capsulata. J Bacteriol 136:201-208

Moisander PH, Shiue L, Steward GF, Jenkins BD, Bebout BM, Zehr JP (2006) Application of a nifH oligonucleotide microarray for profiling diversity of $\mathrm{N}_{2}$-fixing microorganisms in marine microbial mats. Environ Microbiol 8: 1721-1735

> Moisander PH, Morrison AE, Ward BB, Jenkins BD, Zehr JP (2007) Spatial-temporal variability in diazotroph assem- blages in Chesapeake Bay using an oligonucleotide nifH microarray. Environ Microbiol 9:1823-1835

Moisander PH, Beinart RA, Voss M, Zehr JP (2008) Diversity and abundance of diazotrophic microorganisms in the South China Sea during intermonsoon. ISME J 2:954-967

Moore LR, Post AF, Rocap G, Chisholm SW (2002) Utilization of different nitrogen sources by the marine Cyanobacteria Prochlorococcus and Synechococcus. Limnol Oceanogr 47:989-996

Moran MA, Belas R, Schell MA, Gonzalez JM and others (2007) Ecological genomics of marine Roseobacters. Appl Environ Microbiol 73:4559-4569

> Mulholland MR, Capone DG (2000) The nitrogen physiology of the marine $\mathrm{N}_{2}$-fixing Cyanobacteria Trichodesmium spp. Trends Plant Sci 5:148-153

Needoba JA, Foster RA, Sakamoto C, Zehr JP, Johnson KS (2007) Nitrogen fixation by unicellular diazotrophic Cyanobacteria in the temperate oligotrophic North Pacific Ocean. Limnol Oceanogr 52:1317-1327

> Oelze J, Klein G (1996) Control of nitrogen fixation by oxygen in purple nonsulfur bacteria. Arch Microbiol 165:219-225

> Ohki K, Zehr JP, Falkowski PG, Fujita Y (1991) Regulation of nitrogen-fixation by different nitrogen sources in the marine non-heterocystous cyanobacterium Trichodesmium sp. NIBB1067. Arch Microbiol 156:335-337

Paerl HW (1985) Microzone formation: its role in the enhancement of aquatic $\mathrm{N}_{2}$ fixation. Limnol Oceanogr 30: 1246-1252

Paerl HW (1990) Physiological ecology and regulation of $\mathrm{N}_{2}$ fixation in natural waters. Adv Microb Ecol 11:305-344

$>$ Paerl HW, Prufert LE (1987) Oxygen-poor microzones as potential sites of microbial $\mathrm{N}_{2}$ fixation in nitrogendepleted aerobic marine waters. Appl Environ Microbiol 53:1078-1087

Paerl HW, Zehr JP (2000) Marine nitrogen fixation. In: Kirchman DL (ed) Microbial ecology of the oceans. Wiley-Liss, New York, NY, p 387-426

Paulmier A, Ruiz-Pino D (2009) Oxygen minimum zones (OMZs) in the modern ocean. Prog Oceanogr 80:113-128

Ploug H, Kühl M, Buchholz-Cleven B, Jørgensen BB (1997) Anoxic aggregates - an ephemeral phenomenon in the pelagic environment? Aquat Microb Ecol 13:285-294

Polz MF, Cavanaugh CM (1998) Bias in template-to-product ratios in multitemplate PCR. Appl Environ Microbiol 64: $3724-3730$

> Pope MR, Murrell SA, Ludden PW (1985) Covalent modification of the iron protein of nitrogenase from Rhodospirillum rubrum by adenosine diphosphoribosylation of a specific arginine residue. Proc Natl Acad Sci USA 82:3173-3177

> Proctor LM (1997) Nitrogen-fixing, photosynthetic, anaerobic Bacteria associated with pelagic copepods. Aquat Microb Ecol 12:105-113

Ramsing NB, Fossing H, Ferdelman TG, Andersen F, Thamdrup B (1996) Distribution of bacterial populations in a stratified fjord (Mariager Fjord, Denmark) quantified by in situ hybridization and related to chemical gradients in the water column. Appl Environ Microbiol 62:1391-1404

Raymond J, Siefert JL, Staples CR, Blankenship RE (2004) The natural history of nitrogen fixation. Mol Biol Evol 21: $541-554$

Rees AP, Gilbert JA, Kelly-Gerreyn BA (2009) Nitrogen fixation in the western English Channel (NE Atlantic Ocean). Mar Ecol Prog Ser 374:7-12

Ribbe M, Gadkari D, Meyer O (1997) $\mathrm{N}_{2}$-fixation by Streptomyces thermoautotrophicus involves a molybdenum-dinitrogenase and a manganese-superoxide oxidoreductase that couple $\mathrm{N}_{2}$ reduction to the oxidation of superoxide 
produced from $\mathrm{O}_{2}$ by a molybdenum-CO dehydrogenase. J Biol Chem 272:26627-26633

Riemann L, Steward GF, Azam F (2000) Dynamics of bacterial community composition and activity during a mesocosm diatom bloom. Appl Environ Microbiol 66:578-587

Shanks AL, Reeder ML (1993) Reducing microzones and sulfide production in marine snow. Mar Ecol Prog Ser 96: 43-47

Short SM, Zehr JP (2007) Nitrogenase gene expression in the Chesapeake Bay Estuary. Environ Microbiol 9:1591-1596

Short SM, Jenkins BD, Zehr JP (2004) Spatial and temporal distribution of two diazotrophic Bacteria in the Chesapeake Bay. Appl Environ Microbiol 70:2186-2192

Sicking C, Brusch M, Lindackers A, Riedel KU and others (2005) Identification of two new genes involved in diazotrophic growth via the alternative Fe-only nitrogenase in the phototrophic purple bacterium Rhodobacter capsulatus. J Bacteriol 187:92-98

Smith DC, Simon M, Alldredge AL, Azam F (1992) Intense hydrolytic enzyme activity on marine aggregates and implications for rapid particle dissolution. Nature 359: $139-142$

Smith DC, Steward GF, Long RA, Azam F (1995) Bacterial mediation of carbon fluxes during a diatom bloom in a mesocosm. Deep-Sea Res II 42:75-97

Stal LJ (2009) Is the distribution of nitrogen-fixing Cyanobacteria in the oceans related to temperature? Environ Microbiol 11:1632-1645

Stal LJ, Zehr JP (2008) Cyanobacterial nitrogen fixation in the ocean: diversity, regulation, and ecology. In: Herrero A, Flores E (eds) The Cyanobacteria. Molecular biology, genomics and evolution. Caister Academic Press, Norfolk, p 423-446

Steward GF, Jenkins BD, Ward BB, Zehr JP (2004a) Development and testing of a DNA macroarray to assess nitrogenase (nifH) gene diversity. Appl Environ Microbiol 70: 1455-1465

Steward GF, Zehr JP, Jellison R, Montoya JP, Hollibaugh JT (2004b) Vertical distribution of nitrogen-fixing phylotypes in a meromictic, hypersaline lake. Microb Ecol 47 : $30-40$

Tibbles BJ, Rawlings DE (1994) Characterization of nitrogenfixing Bacteria from a temperate saltmarsh lagoon, including isolates that produce ethane from acetylene. Microb Ecol 27:65-80

Turley CM, Mackie PJ (1994) Biogeochemical significance of attached and free-living Bacteria and the flux of particles in the NE Atlantic Ocean. Mar Ecol Prog Ser 115: 191-203

Tyson GW, Chapman J, Hugenholtz P, Allen EE and others (2004) Community structure and metabolism through reconstruction of microbial genomes from the environment. Nature 428:37-43

> Urdaci MC, Stal LJ, Marchand M (1988) Occurrence of nitrogen fixation among Vibrio spp. Arch Microbiol 150: 224-229

> von Wintzingerode F, Göbel UB, Stackebrandt E (1997) Determination of microbial diversity in environmental samples: pitfalls of PCR-based rRNA analysis. FEMS Microbiol Rev 21:213-229

Voss M, Croot P, Lochte K, Mills MM, Peeken I (2004) Patterns of nitrogen fixation along $10^{\circ} \mathrm{N}$ in the tropical Atlantic. Geophys Res Lett 31:L23S09 doi:10.1029/2004 GL020127
Ward BB, Devol AH, Rich JJ, Chang BX, Bulow SE, Naik H, Pratihary A, Jayakumar A (2009) Denitrification as the dominant nitrogen loss process in the Arabian Sea. Nature 461:78-81

> Wasmund N, Voss M, Lochte K (2001) Evidence for nitrogen fixation by non-heterocystous Cyanobacteria in the Baltic Sea and re-calculation of a budget of nitrogen fixation. Mar Ecol Prog Ser 214:1-14

Werner D, Evans HJ, Seidler RJ (1974) Facultatively anaerobic nitrogen-fixing Bacteria from the marine environment. Can J Microbiol 20:59-64

> Wynn-Williams DD, Rhodes ME (1974) Nitrogen fixation in seawater. J Appl Bacteriol 37:203-216

Zani S, Mellon MT, Collier JL, Zehr JP (2000) Expression of nifH genes in natural microbial assemblages in Lake George, New York, detected by reverse transcriptase PCR. Appl Environ Microbiol 66:3119-3124

- Zehr JP, Capone DG (1996) Problems and promises of assaying the genetic potential for nitrogen fixation in the marine environment. Microb Ecol 32:263-281

Zehr JP, McReynolds LA (1989) Use of degenerate oligonucleotides for amplification of the nifH gene from the marine cyanobacterium Trichodesmium thiebautii. Appl Environ Microbiol 55:2522-2526

Zehr JP, Paerl HW (2008) Molecular ecological aspects of nitrogen fixation in the marine environment. In: Kirchman DL (ed) Microbial ecology of the oceans. John Wiley \& Sons, Hoboken, NJ, p 481-525

Zehr JP, Wyman M, Miller V, Duguay L, Capone DG (1993) Modification of the Fe protein of nitrogenase in natural populations of Trichodesmium thiebautii. Appl Environ Microbiol 59:669-676

Zehr JP, Mellon MT, Zani S (1998) New nitrogen-fixing microorganisms detected in oligotrophic oceans by amplification of nitrogenase (nifH) genes. Appl Environ Microbiol 64:3444-3450

Zehr JP, Waterbury JB, Turner PJ, Montoya JP, Omoregie E, Steward GF, Hansen A, Karl DM (2001) Unicellular Cyanobacteria fix $\mathrm{N}_{2}$ in the subtropical North Pacific Ocean. Nature 412:635-638

Zehr JP, Crumbliss LL, Church MJ, Omoregie EO, Jenkins BD (2003a) Nitrogenase genes in PCR and RT-PCR reagents: implications for studies of diversity of functional genes. BioTechniques 35:996-1005

- Zehr JP, Jenkins BD, Short SM, Steward GF (2003b) Nitrogenase gene diversity and microbial community structure: a cross-system comparison. Environ Microbiol 5: $539-554$

Zehr JP, Church MJ, Moisander PH (2006) Diversity, distribution and biogeochemical significance of nitrogen-fixing microorganisms in anoxic and suboxic ocean environments. In: Neretin LN (ed) Past and present water column anoxia. Springer, AZ Dordrecht, p 337-369

Zehr JP, Montoya JP, Jenkins BD, Hewson I and others (2007) Experiments linking nitrogenase gene expression to nitrogen fixation in the North Pacific subtropical gyre. Limnol Oceanogr 52:169-183

Zehr JP, Bench SR, Carter BJ, Hewson I, Niazi F, Shi T, Tripp HJ, Affourtit JP (2008) Globally distributed uncultivated oceanic $\mathrm{N}_{2}$-fixing Cyanobacteria lack oxygenic photosystem II. Science 322:1110-1112

Zhang L, Hurek T, Reinhold-Hurek B (2007) A nifH -based oligonucleotide microarray for functional diagnostics of nitrogen-fixing microorganisms. Microb Ecol 53:456-470 